advanced by the labours of Fergusson, Pollock, Langenbeck, and others, it must be allowed that there are many cases unsuited for any but mechanical treatment, and any improvement in this department will be generally welcomed. The principal novelty in Kingsley's method is the use of soft vulcanised india-rubber to supply the hiatus in the palate, and this, instead of being fixed and immovable, as has hitherto been the custom, is so accurately adapted to the sides of the fissure as to fulfil, in the most complete manner, the functions of the natural palate. The records of cases of congenital malformation thus treated are most encouraging; as are also the cases given by the authors of deformities resulting from operation or disease which they have had under their care. The. work is full of useful information; and as a matter of every-day utility to the practitioner, we may mention the suggestion to adapt a little flap of india-rubber to the mouthpiece of the ordinary infant's feeding-bottle in the case of children born with fissure of the palate, which prevents their sucking, from the impossibility of creating a vacuum in the mouth. Many infants thus malformed undoubtedly sink from the difficulty of feeding them; and the suggestion is one, therefore, of considerable importance.

The Ship Captain's Medical Guide. Compiled by HarRy LEacr, Resident Medical Officer of the Hospital Ship Dreadnought. Second Edition. London: Simpkin, Marshall, and Co. 1868.

A priori it might have been said that Mr. Harry Leach of the Dreadnought was the fit man to write a Medical Guide for Ship Captains under the sanction of the Board of Trade. And the execution of the work shows how good was the selection made by the Board. The directions are in plain, familiar language, and conceived in the spirit of a most wise and judicious practice of physic. We have a new feeling of confidence as we remember that this concise, simple, and good manual is to be the guide of practice on board ship.

The notable additions in this edition are an extension of the valuable chapter on the Prevention of Disease, and a list of the causes of death compiled from the list of diseases recognised by the Registrar-General.

The materia medica of the book is good. The only thing in it we see to question is a little too much leaning to large doses of nitrate of potash-from fifteen to thirty grains. Generally speaking, the doses and the directions for choosing medicines are admirably stated.

\section{DEPOSIT OF SEWAGE MATTER ON THE SHORES OF THE MERSEY, AND THE RECENT OOT- BREAK OF FEVER AT BOOTLE.}

\section{To the Editor of TrEe LANCET.}

Sin,-In your issue of the 10th ultimo you allude to "the generation of gases on the shores (of the Mcrsey) for some miles along the coast" as a primary cause of the recent outbreak of fever at Bootle, a riverain stiburb of Liverpool, and. there can be no doubt that, under special conditions, such a result is conformable with our experience of the effects of putrefying matter elsewhere; but even in the absence of such special conditions, is not a foul condition of some miles of shore, above and below the two important towns of Liverpool and Birkenhead, a constant element in that depression of vital force which is as great an element of danger during the progress of disease as it is an ever-acting disposer to it? The Mersey drains a water-shed containing some millions of inhabitants, who are increasingly pouring their filth and excreta into the stream, which may or may not, after many days of efflux and influx, eventually reach the sea through its deltic channels; but is much more likely, if not certainly, to be deposited on the shores and sand-banks. That the evil and its operation is already recorded may be seen from the following concluding extract from my Report to the Rivers Pollution Commissioners, forwarded to them on the 30th of June last:-

"With the exception of one sewer, which debouches at the head of Tranmere Pool (a creek of the Mersey), all terminate at or near low-water mark in the river. As might be expected, the bed of Tranmere Pool is largely fouled with sewage matter but the same contamination is more or less perceptible on the shores of both sides of the Mersey, and this pollution probably attaches to its bed and to every part of its course, save where the rocks are exposed, or the sand is kept clean by exceptional currents. Even at Hoylake, beyond the river mouth, there are deposits of a very foul claracter brought there by successive fluxes of tidal water, reinforced, it may be, by the dredgings of docks, \&c., habitually carried out and deposited in the current or mid-stream of the river as the speediest and cheapest way of disposing of this refuse.

"I have submitted samples of the river mud to chemical examination from the shore and at low-water mark of the folIowing places-viz., Birkenhead, Liverpool, Tranmere, Rock Ferry, and Hoylake, and have found them to be contaminated with organic matter (mostly sewage) to an extent varying from four to ten and a half per cent. All smelled offensively when warmed, and gave evidence both of ammonia and sulphuretted hydrogen. In one case examined for phosphates, the presence of them was freely ascertained.

"These facts would seem to warrant the inference that the shores of the river would materially affect the salubrity of the adjacent atmosphere, and cloubtless this would be so were it not for the enormous influx and effux of sea-water which takes place with such undeviating constancy in its lower course. In this portion the tidal-water by its solvent, covering, and antiseptic properties, does under very favourable circumstances prevent contamination; but when the protecting tide leaves the mud exposed during the summer heats, or to a hot sun, offensive and injurious gases arise to vitiate the atmosphere, and these have been felt and complained of by various people. A vollution of the river-water is very evident to those who remember its comparatively clear influx some thirty years ago, or to others who are accustomed to the natural clearness of tho sea-water in places less affected by the drainage and sewarge of a populous neighbourhood."

I now subjoin the results in somewhat greater detail of the examination and analyses alluded to, premising that Bromborouch, New Ferry, Rock Ferry, Tranmere, Birkenhead, and New Brighton are places situate on the western shore of the Mersey, reading them off from south to north; while Aigburth, Liverpool, Bootle, and Waterloo are situate on the east shore of the river, and occupy, speaking roughly, a length of seven or eight miles. Hoylake is some dozen miles coastward from

Birkenhead, but borders one of the old channels of the river.

Ist sample: Sandy mud taken from shore, midway between Bromborough Pool and New Ferry, near low-water mark, and where smell was offensive. No sewer visible. It yielded of organic (sewage) matter 4 per cent.

2nd sample: Sandy mud from shore, midway between Rock and Tranmere Ferries, near low water, and where smell was offensive. No sewer near. It gave of organic (sewage) matter 5 per cent.

3rd sample: Filthy black mud from middle of Tranmere Pool, and where smell is rery bad. It gare of organic matter $\mathbf{9} \cdot 5$ per cent.

4tîn sample: Woodside (Birkenhead). Sandy mud from point near luggage-bridge of landing-stage, midway between outlet of two sewers, each about 150 yards distant taken at low-water mark. It gave of organic matter 10.5 per cent.

5th sample: Mud at Aigburth shore presented same character as above, but was not chemically examined.

6th sample: Mud taken from shore under No. 3 bridge of Prince's landing-stage, Liverpool, at low-water mark, and where it smells badly. No sewer outlet visible near. It gave of organic matter $6 \cdot 3$ per cent.

7 th sample: Mud from shore of Waterloo showed same characters as above, but though chemically examined, the results have been mislaid.

8th sample: Mud from banks at low water, Hoylake, and where odour was offensive. It gave of organic matter $5 \cdot 4$ pex cent.

As the westerly winds prevail in this locality, Bootle and Liverpool must be affected more by these emanations than Birkenhead; but no part in the vicinity can entirely escape some injurious effect. The vitiation of atmosphere constantly going on in towns renders it all the more imperative that the circumjacent air which is to dilute it should be pure, especially on that side whence the prevailing winds do blow.

$$
\text { I am, Sir, yours truly, }
$$

C. O. BAYLIS, M.D.,

Birkenhead, Nov. 10th, 1868. Birkenhead Medical Officer of Health. 